\title{
Big Data, AI and Border Enforcement of Intellectual Property Rights
}

\author{
Impact on Trade Flows
}

Xavier Seuba*

\section{A DigitALIZATION OF INTELLECTUAL PROPERTY ENFORCEMENT}

Customs surveillance of intellectual property (IP) is 'an efficient way to quickly and effectively provide legal protection to the right-holder', ${ }^{1}$ since it makes it possible to 'nip the infringements in the bud'. ${ }^{2}$ The World Trade Organization's (WTO) Agreement on Trade-Related Aspects of Intellectual Property Rights (TRIPS) introduced, back in 1995, the first comprehensive multilateral regulation on border measures applicable to goods protected by intellectual property rights (IPRs). ${ }^{3}$ Since then, global trade flows have increased, ${ }^{4}$ new trade agreements regulating IP have substantially modified international intellectual property law ${ }^{5}$ and, most importantly for this chapter's discussion, technology has drastically changed the means and mechanisms of customs enforcement.

* Associate Professor of Law, Academic Coordinator and Scientific Responsible, Center for International Intellectual Property Studies (CEIPI), University of Strasbourg. Contact: xavier .seuba@ceipi.edu.

1 See Regulation No 608/2013 of the European Parliament and of the Council of 12 June 2013 Concerning Customs Enforcement of Intellectual Property Rights and Repealing Council Regulation No 1383/2003, OJ L [2013] 181/15 [hereinafter: EU Regulation No 608/ 2013], at Recital 4, Preamble.

$=$ See M. C. E. J. Bronckers, D. W. F. Verkade, and N. M. McNelis, TRIPS Agreement: Enforcement of Intellectual Property Rights (Luxemburg: Publications Office of the EU, 2000), at 20.

3 See Articles 51-6o Agreement on Trade-Related Aspects of Intellectual Property Rights, 1869 U.N.T.S. 299; 33 I.L.M. 1197 (1994), entered into force 1 January 1995 [hereinafter: TRIPS].

4 See E. Ortiz-Ospina and D. Beltekian, 'Trade and Globalization', Our World in Data, 2018, available at https://ourworldindata.org/trade-and-globalization.

5 See R. Valdés and R. Tavengwa, 'Intellectual Property Provisions in Regional Trade Agreements', WTO Staff Working Paper No 21 (2012); X. Seuba, 'Intellectual Property in Preferential Trade Agreements: What Treaties, What Content?', The Journal of World Intellectual Property 16 (2013), 1-22; P. Roffe and X. Seuba (eds), Global Perspectives and Challenges for the Intellectual Property System: Current Alliances in International Intellectual Property Lawmaking (Geneva/Strasbourg: CEIPI/ICTSD, 2017). 
Technological developments increase the possibilities of identifying and detaining goods infringing IPRs, and make it more feasible to 'assess in advance and control where required', which is the ideal pattern of action from a customs' risk management perspective. ${ }^{6}$ However, assessing in advance and acting when appropriate does not always match well with fundamental intellectual property principles (territoriality), global trade norms (freedom of transit), global intellectual property rules (Articles 51 and 52 TRIPS), and due process requirements. This chapter, in light of these basic norms and principles, explores some of the challenges and opportunities brought by artificial intelligence (AI), big data and distributed ledger technologies to customs enforcement of IPRs. ${ }^{7}$

\section{B HOW ARTIFICIAL INTELLIGENCE TRANSFORMS INTELLECTUAL}

\section{PROPERTY ENFORCEMENT}

Fuelled by a profusion of digitized data and rapidly advancing computational processing power, ${ }^{8} \mathrm{AI}$ techniques and functional applications ${ }^{9}$ give rise to unprecedented opportunities of innovation and creativity, and also bring about important challenges to intellectual property protection. ${ }^{10}$ Three major areas stand out.

First, the use of AI techniques to generate innovative and creative products has prompted discussion concerning the need, extent and legal grounds for the IP protection of products developed thanks to AI. ${ }^{11}$ Second, regarding the means that enable

6 European Commission, Communication on the EU Strategy and Action Plan for Customs Risk Management: Tackling Risks, Strengthening Supply Chain Security and Facilitating Trade, $\operatorname{COM}(2014) 0527$ final, 21 August 2014.

7 See also Chapter 6 in this volume.

8 WIPO, WIPO Technology Trends 2019: Artificial Intelligence (Geneva: WIPO, 2019), at 13.

9 AI techniques include machine learning, deep learning, fuzzy logic, logic programming, neutral networks, latent representation and unsupervised learning. AI functional applications include computer vision (including image recognition and biometrics), natural language processing (including semantics and sentiment analysis), speech processing (speech-to-speech and speaker recognition), robotics, control methods. See WIPO, note 8, at 31 .

${ }^{10}$ On policy issues, see the interview with the Director General of WIPO Francis Gurry. WIPO, 'Artificial Intelligence and Intellectual Property: An Interview with Francis Gurry', WIPO Magazine, September 2018. WIPO has also made available a website on 'Artificial Intelligence and Intellectual Property' with information and practical resources, available at www.wipo.int/ about-ip/en/artificial_intelligence/.

${ }^{11}$ As H. Pihlajamaa underlines, AI poses challenges to inventorship and ownership, patent eligibility, assessment of inventiveness, and sufficiency of disclosure. See H. Pihlajamaa, 'Summary of Feedback by EPC Contracting States: Legal Aspects of Patenting Inventions Involving Artificial Intelligence (AI)', Committee on Patent Law of the European Patent Office, 20 February 2019. A vast body of literature already addresses these challenges. See, e.g., T. L. Butler, 'Can a Computer Be an Author - Copyright Aspects of Artificial Intelligence', A Journal of Communications and Entertainment Law 4 (1982), 707-748; A. Lauber-Rönsberg and S. Hetmank, "The Concept of Authorship and Inventorship under Pressure: Does Artificial Intelligence Shift Paradigms?', Journal of Intellectual Property Law and Practice 14 (2019), 570-579; R. Abbott, 'I Think, Therefore I Invent: Creative Computers and the Future of Patent Law', Boston College Law Review 57 (2016), 1079-1126; N. Shemtov, 
creation and innovation, the intellectual property protection of $\mathrm{AI}$ techniques and functional applications per se has skyrocketed in recent years. ${ }^{12}$ Third, the use of AI, big data and distributed ledger technologies also impacts IP enforcement. The increase of available information and the changes in the techniques used to make such information useful impact fundamental aspects of intellectual property enforcement. These changes revolve around three concepts: authority, automation and centralization.

A substantial change concerns the authority in charge of law enforcement and the process of privatization of law enforcement by means of delegation of public authority. ${ }^{13} \mathrm{~A}$ telling example is that of online intermediaries, ${ }^{14}$ which have acquired a central role in managing behaviour in the digital environment. ${ }^{15}$ From free speech to access to information, many issues are mediated by search engines, websites and social networks. Their power also expands to intellectual property enforcement, since online intermediaries not only identify infringement, but also produce the information regarding the infringing activity, the infringers, the channels of commerce and its financial aspects. ${ }^{16}$ Intermediaries furthermore use algorithms to remove allegedly infringing content upon notice of infringement, as well as to ex ante monitor, filter, block and disable access to content automatically flagged as infringing. ${ }^{17}$

A Study on Inventorship in Inventions Involving AI Activity (Munich: EPO, 2019). See also Chapter 7 in this volume.

${ }_{12}$ P. Cupitt, 'Patenting Artificial Intelligence at the European Patent Office', CIPA Journal, April 2019.

13 For examples, see WIPO, Study on Approaches to Online Trademark Infringements, WIPO/ ACE/12/9 REV. 2, 31 July 2017, at 9-12.

${ }^{14}$ G. Frosio, 'Why Keep a Dog and Bark Yourself? From Intermediary Liability to Responsibility', Oxford International Journal of Law and Information Technology 25 (2017), 1-33; European Commission, Communication on Online Platforms and the Digital Single Market Opportunities and Challenges for Europe, $\mathrm{COM}(2017) 555$ final, 28 September 2017. On the responsibility of intermediaries themselves, see, e.g., K. Weatherall, 'Internet Intermediaries and Copyright - A 2018 Update: A Policy Paper for the Australian Digital Alliance', Parliament of Australia: Copyright Amendment (Service Providers) Bill 2017, Submission 37, 11 February 2018; E. Rosati, 'The CJEU Pirate Bay Judgment and Its Impact on the Liability of Online Platforms', European Intellectual Property Review 39 (2017), 737-748; J. Ginsburg and J. A. Budiardjo, 'Liability for Providing Hyperlinks to Copyright-Infringing Content: International and Comparative Law Perspectives', Columbia Joumal of Law and the Arts 41 (2018), 153-224.

15 M. Perel and N. Elkin-Koren, 'Black Box Tinkering: Beyond Transparency in Algorithmic Enforcement', Florida Law Review 69 (2017), 181-221, at 190. This is a power that platforms do not necessarily wish to have. Google 'didn't ask to be the decision maker' on deletions, as Google’s Executive President Eric Schmidt stated. See A. White, 'Google EU Ruling Response Vetted as Complaints Pile Up', Bloomberg, 18 September 2014.

${ }^{16}$ For instance, Chinese giant Alibaba leads the use of big data analytics and machine learning and sets a cutting-edge standard in the area. Alibaba automated systems flag a product as counterfeit. Next, the system pools financial and commercial information and identities counterfeiters, and probably the manufacturing site and movement of funds. See Alibaba, Alibaba IPR Protection Handbook (Hangzhou: Alibaba, 2019).

${ }^{17}$ For a list of authors and works that have discussed the function of Internet intermediaries as gatekeepers, see M. Perel and N. Elkin-Koren, 'Accountability in Algorithmic Copyright Enforcement', Stanford Technology Law Review 19 (2016), 473-533, at 480 and 485. 
Privatization leads to the convergence of law enforcement and adjudication powers. ${ }^{18}$ Private stakeholders that identify infringing products also apply the corresponding sanctions of destroying infringing goods and cutting access to the Internet. The conventional way of functioning has been drastically altered. Customs officials, police and judges have always been part of the enforcement process, which encompasses a variety of interrelated activities. However, the substitution of these actors by private operators gives rise to the concentration of functions in the hands of a single actor. While this may certainly enhance efficacy and may be the adequate response to the volume of current trade, it also raises concerns from the point of view of independence, accountability ${ }^{19}$ and fair trial standards.

A second and related phenomenon concerns automation - that is, the fact that machines themselves implement the law. Computers use machine learning techniques to derive legal consequences, implement orders and reach conclusions from a database of primary sources. ${ }^{20}$ In addition to automated processes that apply to all branches of the law, there are sui generis types of automation applicable to IP. For instance, machines may respond to copyright-based Internet takedown requests, and may also determine the existence of trademark infringement thanks to image recognition. ${ }^{21}$ The changes brought about by AI do not merely impact the online environment but also the manner in which judges adjudicate IP cases, lawyers practice IP law and authorities, including customs authorities, identify infringement. While due process concerns arise, ${ }^{22}$ many start-ups have developed applications that are transfiguring law practice, ${ }^{23}$ in particular those that enable the automation of time-consuming processes, such as conducting research, writing memos, undertaking due diligence and collecting evidence. ${ }^{24}$ Automation of the

${ }^{18}$ Ibid., at 481 .

19 Ibid., at 477 .

${ }^{20}$ S. Morse, 'Government-to-Robot Enforcement', University of Illinois Law Review 5 (2019), $1497^{-1525}$.

${ }^{21}$ For instance, in 2014 WIPO added image-search to its Global Brand Database, allowing users to search for visually similar trademark from among the millions of images in the collection. See WIPO, 'WIPO Launches Unique Image-Based Search for Trademarks, Other Brand Information', Press Release, 12 May 2014. Private developers have brought to the market applications that allow to conduct similar analyses, among them, TrademarkNow, TrademarkVision, MikeTM Suite and LawPanel's Aila. Other applications allow to spot fakes just by scanning with a phone device. This is, for instance, the case of Entrupy and Goat.

${ }^{22}$ D. K. Citron and F. Pasquale, 'The Scored Society: Due Process for Automated Predictions', Washington Law Review 89 (2014), 1-34

${ }_{23}$ B. Rubin, 'Legal Tech Startups Have a Short History and a Bright Future', TechCrunch, 6 December 2014; M. McKamey, 'Legal Technology: Artificial Intelligence and the Future of Law Practice', Appeal 22 (2017), 45-58, at 57; E. A. Rayo, 'AI in Law and Legal Practice A Comprehensive View of 35 Current Applications', Emeri, 29 November 2017.

24 M. R. Grossman and G. Cormack, 'Technology-Assisted Review in E-Discovery Can Be More Effective and More Efficient Than Exhaustive Manual Review', Richmond Journal of Law and Technology 17 (2011), 1-48, at 11; D. Garcia, 'Preparing for Artificial Intelligence in the Legal Profession', Lexis Practice Advisor Journal, 6 July 2017. 
law is promoted invoking practical advances in terms of efficiency, savings, consistency in applying legal doctrines and legal harmonization. ${ }^{25}$

A third change relates to centralization. Under this term, reference is made to the fact that a single action - writing a bit of software code - produces legal decisions for many individuals at once. ${ }^{26}$ These are decisions that have previously required an individualized procedure. ${ }^{27} \mathrm{Up}$ until recent times, enforcement was human-driven, dynamic, public and individualized. Public authorities enforcing intellectual property - judges, customs officials and police - were 'just' humans. Similarly, intellectual property could not be understood as an automated process, but as a process of weighing and balancing competing rights and interests, ${ }^{28}$ a process taking place in an individualized fashion in public settings and administered either by judicial or administrative authorities. These features contrast with a new situation where enforcement mechanisms are automated, centralized and privatized, and big (private) players occupy the place of public authorities.

\section{DigitAlizATION AND USE OF BIG DATA IN CUSTOMS CONTROL}

\section{Digitalization and Customs Control}

While international logistics value chains are still characterized by the abundance of manual and paper-based processes, digitalization and $\mathrm{AI}$ are already transforming customs control. For instance, in the area of migration control, international travellers face, more and more often, semi-automated border controls that combine biometric screening, ${ }^{29}$ facial recognition, automated lie detection and predictive

25 Perel and Elkin-Koren, note 17, at 477. For a more critical and analytic view on the phenomenon, see D. Remus and F. S. Levy Frank, 'Can Robots Be Lawyers? Computers, Lawyers, and the Practice of Law', Georgetown Journal of Legal Ethics 30 (2017), 501-558; A. Marwaha, 'Seven Benefits of Artificial Intelligence for Law Firms', Law Technology Today, 13 July 2017.

26 Morse, note 20.

27 As Lessig stated in his acclaimed 2000 piece, in the age of cyberspace the regulator is code the software and hardware that make cyberspace as it is. This code, or architecture, sets the terms on which life in cyberspace is experienced. It determines how easy it is to protect privacy, or how easy it is to censor speech'. See L. Lessig, 'Code Is Law. On Liberty in Cyberspace', Harvard Magazine, 1 January 2000; also L. Lessig, Code and Other Laws of Cyberspace (New York: Basic Books, 1999).

28 The same applies to other legal domains. For instance, the WTO Appellate Body has noted: 'In sum, determination of whether a measure, which is not "indispensable", may nevertheless be "necessary" within the contemplation of Article XX(d), involves in every case a process of weighing and balancing a series of factors which prominently include the contribution made by the compliance measure to the enforcement of the law or regulation at issue, the importance of the common interests or values protected by that law or regulation, and the accompanying impact of the law or regulation on imports or exports'. See Appellate Body Report, Korea - Measures Affecting Imports of Fresh, Chilled and Frozen Beef (Korea - Various Measures on Beef), WT/DS161/AB/R, adopted 11 December 2000, at para. 164.

29 The EU has given impulse to a gigantic biometrics database, the Common Identity Repository (CIR), which interconnects border-control, migration and law enforcement systems into a 
modelling. ${ }^{30}$ Likewise, predictive analytics also transform and enhance customs risk management regarding both the control of people and the monitoring of goods.

AI functional applications, such as computer vision, natural language processing and predictive analytics, are powered by the vast amount of data available in digitalized forms. Given the importance of data, a previous step is the digitalization of customs operations, an area that is characterized by red tape $\mathrm{e}^{31}$ and the existence of a vast amount of valuable information transmitted in each transaction..$^{32}$

In the European Union, digitalization of customs was initiated back in the late $199 \mathrm{os}^{33}$ and dynamically promoted in 2008 with the adoption of the decision on a paperless environment for customs and trade. ${ }^{34}$ The 'e-Customs Decision' identified the objectives, means and framework for setting up an electronic environment for customs and trade, ${ }^{35}$ and was followed by the electronic customs Multi-annual

biometrics-tracking database of $\mathrm{EU}$ and non-EU citizens, thus simplifying the work of customs authorities. See C. Cimpanu, 'EU Votes to Create Gigantic Biometrics Database', ZDNet, 22 April 2019.

30 This is, for instance, the case of the United States system AVATAR, an automated lie detection system that makes probabilistic decisions about veracity of statements: judgements about whether someone is telling the truth thanks to sensors of eye movements, body movements and voice.

${ }^{31}$ According to a frequently quoted statement of the UNCTAD 2004 Trade and Development Report, 'the average customs transaction involves 20-30 different parties, 40 documents, 200 data elements (30 of which are repeated at least 30 times) and the re-keying of $60-70 \%$ of all data at least once'. See WTO, Annual Trade Report 2019 (Geneva: WTO, 2019); also WTO, Trade Facilitation, available at www.wto.org/english/tratop_e/tradfa_e/tradfa_e.htm.

$3^{2}$ Before arriving to customs, goods are declared using the 'Single Administrative Document' (SAD), which in the EU is lodged electronically on the relevant customs system. The electronic data transfer captures information about the importing shipment, such as the Commodity Code, which provides the description of the product being shipped, and the Customs Procedures Code, which describes the procedure and/or regime under which the goods are being imported. Other important data elements contained on the SAD are importing country/business unit; ship from name/DUNS; ship to name/DUNS/plant code; description; quantity; value; country of origin; country of export; HS Code; free trade agreement status; amount of duty paid; mode of transportation; category (Prod/P\&A/VEH/M\&E); entry/invoice detail; import-related taxes and fees.

33 The 'New Computerised Transit System' (NCTS) set up an EU-wide electronic exchange of customs declarations in 1997. The harmonization of customs forms started well before: in 1985 the Single Administration Document defined the common data elements to be used across the then European Community. See Council Regulation No 1900/85 of 11 July 1985 Introducing Community Export and Import Declaration Forms, OJ L [1985] 197/4.

34 Decision No 70/2008/EC of the European Parliament and of the Council of 15 January 2008 on a Paperless Environment for Customs and Trade, OJ L [2008] 23/21 [hereinafter: e-Customs Decision].

35 Article 1 E-Customs Decision obliges the commission and member states to 'set up secure, integrated, interoperable and accessible electronic customs systems for the exchange of data contained in customs declarations, documents accompanying customs declarations and certificates and the exchange of other relevant information. The Commission and the Member States shall provide the structure and means for the operation of those electronic customs systems'. 
Strategic Plan. ${ }^{36}$ Since 2016, the Union Customs Code sets the framework on the rules and procedures for customs in the European Union. ${ }^{37}$ Crucially, it mandates that 'all exchanges of information ... as required under the customs legislation, shall be made using electronic data-processing techniques' and identifies 2020 as the deadline for a paperless customs union. ${ }^{3}$

The compromise to move towards digitalized customs management has been extended to European Union trade partners via free trade agreements. The border enforcement sections of the intellectual property chapters of those trade agreements include compromises and best efforts-type of provisions to adopt digital management systems to monitor customs procedures. For instance, in the border enforcement sections of the 2019 EU association agreements with Japan and Vietnam, the use of electronic systems for the management of customs by applications of IP holders is encouraged, and the use of risk analysis to identify goods suspected of infringing IPRs is mandated. ${ }^{39}$

\section{Big Data, Customs Control and Risk Analysis}

In the area of customs enforcement, big data provides new knowledge, drives value creation, fosters new processes and enhances well-informed decision making..$^{\circ}$ Reference is commonly made to three characteristics of big data: ${ }^{41}$ high-volume, high-speed and high-variety of information assets..$^{2}$ The fact that big data is made up

${ }^{6}$ The Multi-Annual Strategic Plan (MASP) is a joint EU commission-member states management instrument that establishes the strategic framework and objectives for implementation of the e-Customs initiative.

37 Article 6 Regulation No 952/2013 of the European Parliament and the Council of 9 October 2013 Laying Down the Union Customs Code, OJ L [2013] 269/1 [hereinafter: Union Customs Code Decision]. See also Article 16.1 Union Customs Code Decision, establishing that 'Member States shall cooperate with the Commission to develop, maintain and employ electronic systems for the exchange of information between customs authorities and with the Commission and for the storage of such information'.

$3^{8}$ Articles 16, 278 and 280 of Union Customs Code Decision mandate developing a work programme for the development of electronic systems, relying of the previously existing multi-annual strategic plan and providing a timeline for the update and creation of electronic customs systems until the end of 2020. See also Regulation No 1294/2013 of the European Parliament and the Council of 11 December 2013 Establishing an Action Programme for Customs in the European Union 2014-2020 (Customs 2020) and Repealing Decision No 624/2007/E, OJ L [2013] 347/209.

39 See, respectively, Articles 14.51(2) of the Japan-EU EPA and Article 12.59 of the Vietnam-EU FTA and the Investment Protection Agreement.

$4^{\circ}$ Y. Okazaki, 'Implications of Big Data for Customs - How It Can Support Risk Management Capabilities', WCO Research Paper No 39 (2017).

${ }^{41}$ There is no single definition of big data. See J. S. Ward and A. Barker, 'Undefined by Data: A Survey of Big Data Definitions', arXiv:1309.5821v1, 20 September 2013. See also Chapter 7 in this volume.

$4^{2}$ TechAmerica Foundation, Demystifying Big Data: A Practical Guide to Transforming the Business of Government (Washington, DC: TechAmerica Foundation, 2012). 
of 'extremely large data sets' 43 echoes another, implicit, characteristic: most often, big data is made of 'raw' information of both public 44 and private nature which is incomplete and imperfect.

Big data enhances the potential of descriptive, predictive and prescriptive data analytics, namely the obtention of raw data and the examination of that information with the purpose of identifying patterns, drawing conclusions, predicting the future and providing the best solution. ${ }^{45}$ Regarding risk management in the area of customs enforcement, big data allows to predict threats, monitor trends and target high-risk transactions. Nowadays, both descriptive risk rating and prescriptive risk management have been incorporated into customs enforcement operations. This is where text analytics, data mining, statistics, natural language processing and machine learning offer valuable information and display patterns of infringing activities.

Automation and learning from past events enhance the efficiency of selecting risky cargos, in particular by identifying suspicious networks and transactions. Automation also facilitates the estimation of potential loses and damages. Additionally, image recognition is of relevance to trademark counterfeiting. In this regard, analysis and exploitation of images for automatic verification of consistency against available information is instrumental to perform customs risk management intended to fight counterfeiting. ${ }^{6}$ Devices and software developed to spot fakes in ordinary places of commerce, such as shops, ${ }^{47}$ can be adapted to conduct similar preliminary assessments by customs authorities.

The question that arises is how to take bigger advantage of currently existing technical capacities and amounts of data. Three aspects seem critical: First, it is necessary to ensure the quality of data regarding cargos, shipments and conveyances, and also relevant information concerning intellectual property rights. Incompleteness and heterogeneous data formats ${ }^{4}$ make it more difficult to efficiently use information

43 That may be analyzed computationally to reveal patterns, trends and associations, especially relating to human behaviour and interactions.

44 Customs administrations compile data they already possess and data they obtain from other authorities and areas of public administration. See, for example, for internal use of customs data by the same customs authorities the case of the United States Customs and Border Protection; and, for the case of inter-agency sharing and use, the case of Hong Kong China Customs' Central Information Repository. See Okazaki, note 40, at 9, 11.

45 L. Keyes, 'Data Analytics. How Data Analytics Can Simplify and Facilitate Trade within the European Union', Europese Fiscale Studies (2015/2016), at 4-5. On analytics, see T. H. Davenport and J. G. Harris, Competing on Analytics: The New Science of Winning (Cambridge, MA: Harvard Business School Press, 2007), at 7.

$4^{6}$ See, more broadly, Policy Background for Customs Risk Management: Practitioners' Guidance Document (Brussels: European Union, 2017).

47 Simply by scanning suspect goods, one can identify infringement. The information provided feeds and makes the system richer and more performing for future occasions. M. Arrison, 'State of the Fake: 2019 Report', Entrupy, 2019.

$4^{8}$ As noted, 'developing agreed formats and standards in the exchanging of data' would increase the efficiency of trade and enhance transparency. Keyes, note 45 , at 3 . 
for analytical purposes. ${ }^{49}$ Second, it is also important to widen the scope of the data used for analytical purposes. In this last respect, a possibility is to go beyond data of purely customs nature and correlate such data with, for instance, tax, crime or IPrelated information..$^{\circ}$ Third, it is also necessary to overcome country differences in terms of capacity to implement common risk criteria and standards, ${ }^{51}$ and to efficiently address IP infringement having a border enforcement component.

\section{Distributed Ledger Technologies and Localization of Traded Goods}

Distributed ledger technologies allow moving from a single administrator who controls the ledger where information is stored to a ledger shared by a network of stakeholders. None of the members of the network has autonomous control and all changes made by a member of the network are visible and transparent. ${ }^{52} \mathrm{~A}$ wellknown example of public distributed ledger technology 53 is blockchain, which enables the recording of transactions between parties in a secure and permanent way while removing intermediaries that previously verified transactions - a function that is of relevance to many economic and technological fields. ${ }^{54}$

Efficiency, velocity, transparency, traceability and automation are the main advantages brought by distributed ledger technologies to international logistics and commercial processes.55 Distributed ledger technologies significantly reduce bureaucracy and paperwork, ${ }^{56}$ and may also enable new business models ${ }^{57}$ and

49 Big data contains both structured and unstructured data formats. The use of unstructured data represents an important challenge for customs administrations, which are used to formularies and forms that are adjusted to the international standards of the WCO and the United Nations Electronic Data Interchange for Administration, Commerce and Transport. The latter is the international standard for electronic data interchange (EDI). See Okazaki, note 40, at 14.

50 See below the example given in the case of goods in transit.

${ }^{51}$ For the EU, see for instance note 46.

${ }^{52}$ For a clear and concise explanation of distributed ledger technologies, see M. Tripoli and J. Schmidhuber, Emerging Opportunities for the Application of Blockchain in the Agri-Food Industry (Geneva: ICTSD, 2018), at 3-5. See also Chapter 6 in this volume.

53 A public distributed ledger technology is an open ledger with free access.

54 Patent families of blockchain technologies allow the observation of the technology fields where most patents are filed which, in order, are (i) payment architectures, schemes or protocols; (ii) cryptographic mechanisms or cryptographic arrangements for secret or secure communication; (iii) network architectures or network communication protocols for network security; (iv) security arrangements for protecting computers; (v) finance; insurance; tax strategies; (vi) commerce, e.g. shopping or e-commerce; (vii) digital computing or data processing equipment or methods; (viii) data processing systems or methods; (ix) network-specific arrangements or communication protocols supporting networked applications. See Y. Ménière, "The Emerging Blockchain Patent Landscape', Presentation at EPO Conference on Patenting Blockchain, 4 December 2018, at 8.

55 DHL Trend Research, Blockchain in Logistics (Troisdorf: DHL Customer Solutions and Innovation, 2018), at 2.

56 Ibid., at 4 .

57 For instance, digital identities, certificates, tamper-proof documents. 
enhance asset management..$^{8}$ They furthermore make it possible to obtain information in respect of manufacturing practices, quality attributes and place of origin. In the area of intellectual property, traceability is among the most visible advantages brought by distributed ledger technologies, in particular for goods protected by IPRs that identify the origin of goods (geographical indications) and for goods protected by IPRs that enable consumers to identify specific producers, characteristics and qualities (trademarks).

A particularly valuable application in the area of customs control is the possibility offered by the Internet of Things (IoT) to capture the location, condition and status of traded goods in real time. ${ }^{59}$ This allows logistics service operators to detect irregularities affecting the cargos, improve supply chain control and detect the introduction of fake products. In order to take full advantage of distributed ledger technologies, track and trace methods should ideally allow interaction, which means that some physical devices may be embedded in the traded goods that are object of control.

Track and trace methods belong to the broader group of anti-counterfeiting technologies, which include overt and covert authentication technologies that determine whether a product is original, and allow for enhanced control within the supply chain. Regarding authentication technologies, overt technologies are accessible using human senses, such as vision and touch, thus they do not need any specific physical device, ${ }^{60}$ while covert technologies are hidden and only accessible to technology providers, brand owners or authorized stakeholders. ${ }^{61}$ In respect of track and trace technologies, optical methods and Radio Frequency Identification (RFID) tags stand out. ${ }^{62}$ Both of them allow for the localization of the product along the production and distribution chain: optical technologies consist of a code that contains information on the product and is affixed on the product itself, ${ }_{3} 3$ whereas RFID tags can be read by radio

${ }^{8}$ It can be used to manage the ownership of digital assets and facilitate asset transfers. See DHL Trend Research, note 55, at 6.

59 Digitalization of trade flows and end-to-end shipment tracking are objectives of collaboration between logistics and technology companies. The goal is to allow monitoring the progress of goods through the supply chain, overview the status of customs controls, view bills of lading and other data. On the collaboration between Maersk and IBM, see 'Maersk IBM Form Joint Venture Applying Blockchain to Improve Global Trade and Digitize Supply Chain', SupplyChain247, 8 January 2018.

6o Among the drawbacks of these technologies, mention is commonly made of easier imitation, possible reuse and false assurance. See C. Smith, Ensuring Supply Chain Security: The Role of Anti-Counterfeiting Technologies (Torino: UNICRI, 2016), at 16. These technologies include holograms, color-shifting inks, security threads, micro-printing, bar-code technology and watermarks.

${ }^{61}$ Among the drawbacks noted in respect to these technologies, mention is commonly made of easier potential imitation, possible reuse and possible false assurance. Smith, note 60, at 16.

62 Other include EPCs, barcodes, QR codes, datamatrix codes and web portal tools.

63 Examples in the area of medicines and tobacco control are the Council of Europe Unique Medicine Identifier 'eTACT'; see Article 15 Directive 2014/40/EU of the European Parliament 
waves. ${ }^{64}$ As it has been noted, 'smart devices can be securely tied to or embedded in the physical product to autonomously record and transmit data about item condition including temperature variation, to ensure product integrity, as well as any evidence of product tampering. ${ }^{65}$ In the area of pharmaceutical products, for instance, this allows to asses at the same time several types of IP infringement and the compliance with regulatory standards.

\section{LEGAL CHALLENGES AND OPPORTUNITIES}

The control of intellectual property protected goods in transit ${ }^{66}$ exemplifies well how existing legal challenges can be addressed resorting to AI applications and big data.

\section{Opportunities}

TRIPS does not require the control of goods protected by IPRs in transit, nor the monitoring of exports. It just orders impeding the importation of counterfeit and pirated goods. ${ }^{67}$ Building on this minimum standard, a significant number of countries has enacted legislation that goes beyond such protection, ${ }^{68}$ thus it is nowadays usual to find countries that control exports and, to a lesser extent, the transit of IP protected goods. This is particularly the case with trademark and copyright protected goods, but some countries also monitor goods protected by other IP categories. ${ }^{69}$

and of the Council of 3 April 2014 on the Approximation of the Laws, Regulations and Administrative Provisions of the Member States Concerning the Manufacture, Presentation and Sale of Tobacco and Related Products and Repealing Directive 2001/37/EC, OJ L [2014] $127 / 1$.

${ }^{6}$ Smith, note 60 , at 17 .

65 DHL Trend Research, note 55, at 16.

66 Terminology varies across countries. In the EU, suspensive or 'special procedures' - in the terminology used in the 2008 Modernised Customs Code - include several possibilities: transit (external and internal); storage (temporary storage, customs warehousing and free zones); specific use (temporary admission and end-use) and processing (inward and outward processing). See Article 135 Regulation No 450/2008 of the European Parliament and of the Council of 23 April 2008 Laying Down the Community Customs Code (Modernised Customs Code), OJ L [2008] 145/1.

${ }^{6}$ See Article 51 TRIPS, which establishes that, in respect to customs operations that must be controlled, members must allow an application to be lodged for the suspension of the release into free circulation of imported counterfeit and pirated products.

68 For instance, pursuant to EU Regulation No 608/2013, authorities must supervise goods when declared for release for free circulation, in the cases of exportation or re-exportation, when entering or leaving the customs territory of the European Union, and when placed under a suspensive procedure or in a free zone or free warehouse.

69 Some agreements refer not only to counterfeit and pirated goods, but to all types of trademark and copyright infringements. A smaller but increasing number of trade agreements include the obligation to control categories of intellectual property rights distinct from trademarks and 
In the case of the control of goods in transit, the goal of the country of transit is to impede the arrival of products to foreign jurisdictions. This may generate tensions with two fundamental principles - the principle of territoriality of IP protection and the principle of freedom of transit of internationally traded goods. Such tension is severe in respect of the principle of territoriality, since some countries have put in place customs controls of goods in transit that disregard the status of IP protection in the country of origin and in the country of destination. In these cases, seizure and eventual destruction are decided according to the law of the country of transit, hence eroding the principle of territoriality. In the case of the principle of freedom of transit, the tension is also acute, and both legal reform and courts have qualified the cases where restriction of freedom of transit is acceptable to control goods protected by IPRs. The legal standards developed are intended to preserve the balance between adequate IP protection and the principles just referred to. As argued earlier, however, they could benefit from technological advances in the area of big data and AI.

Pursuant to EU Regulation No 608/2013, goods are suspected of infringing an intellectual property right if there are indications that where such goods are found in a member state, they are the subject of an act infringing an intellectual property right. $^{70}$ However, the mere transit of goods through a country where they are protected does not imply an infringement. ${ }^{71}$ In response to the heated debates arising from the detention of medicines in transit, ${ }^{72}$ EU Regulation No 608/2013 stated that "customs authorities should, when assessing a risk of infringement of intellectual property rights, take account of any substantial likelihood of diversion of such medicines onto the market of the Union'. ${ }^{73}$ The Court of Justice of the European Union (CJEU) linked the detention and the suspension of release of

copyright. This is the case of treaties that order the control of patents, designs, geographical indications, utility models and plant varieties.

70 See Article 2.7(a) EU Regulation No 608/2013.

${ }^{71}$ The CJEU adopted in 2011 a seminal judicial decision on the temporary detention and eventual destruction of goods placed under a suspensive procedure. In its reply to the joined Philips and Nokia cases, the CJEU restated its previous jurisprudence, holding that the mere placement of goods under a suspensive procedure does not entitle right holders to request the detention of goods, and that no infringement of IPRs can be found if there is no evidence of the potential diversion of goods. See CJEU, Joined Cases C-446/og and C-495/o9, Koninklijke Philips Electronics NV (C-446/o9) v. Lucheng Meijing Industrial Company Ltd and Others and Nokia Corporation (C-495/o9) v. Her Majesty's Commissioners of Revenue and Customs [2011], ECR I-12435.

72 F. M. Abbott, 'Seizure of Generic Pharmaceuticals in Transit Based on Allegations of Patent Infringement: A Threat to International Trade, Development and Public Welfare', WIPO Journal 1 (2009), 43-50; H. Grosse Ruse-Khan and T. Jaeger, 'Policing Patents Worldwide? EC Border Measures against Transiting Generic Drugs under EC and WTO Intellectual Property Regimes', International Review of Intellectual Property and Competition Law 40 (2009), 502-538; X. Seuba, Free Trade of Pharmaceutical Products: The Limits of Intellectual Property Enforcement at the Border (Geneva: ICTSD, 2010), at 9.

73 See Recital 11 and Article 1.5 EU Regulation No 608/2013. 
protected goods in transit to the potential diversion of those goods onto the transited market, thus only by placing the goods in the internal market can the subject matter of a specific intellectual property right be infringed. ${ }^{74}$ Likewise, if goods are the subject of a commercial act directed to European consumers, intellectual property rights may be infringed and goods placed under a suspensive procedure may be detained. The risk of fraudulent diversion to European consumers may also arise in other circumstances, even when goods have not yet been directed towards European consumers. Customs authorities can, in effect, detain the goods or suspend their release when there are indications that commercial activities may take place in the near future or are being disguised. ${ }^{75}$ Suspicion, based on a number of facts of the case, will suffice for that purpose. The CJEU gave a number of examples, including the destination of the goods not being declared, the lack of precise or reliable information as to the identity or address of the manufacturer or consignor of the goods, a lack of cooperation with the customs authorities, or the discovery of documents suggesting that there is a likelihood of a diversion of those goods to EU consumers. ${ }^{76}$

The control of the scenarios described in the paragraph above is difficult in the daily operation of customs control. Some of the examples given by the CJEU require that customs officials and/or right holders have access to information that, most often, is not publicly available. On other occasions, the volume of internationally traded goods makes it almost impossible to manage existing information. These are problems, however, that big data and AI can help to overcome. In the first case, if the use of distributed ledger technologies and track and trace technologies became general, the efficiency of control would increase exponentially. As explained by Okazaki, advanced sensor technology 'allows logistics service providers to detect any irregularities occurring in or around the cargos in transit, thus helping to enhance supply chain security. As such, a containerized cargo being once regarded as "low-risk" or "risk-free" can maintain the same condition until it is delivered at the destination unless any suspicious intervention is detected during the time of transport'. $7^{7}$

Management of data at the international level can also be instrumental in another, very practical, context. In order to protect IP, some countries have introduced legal regimes that, while allowing to take action regarding goods in transit, still differ from the EU model described earlier. An interesting, while controversial,

74 Ibid., at para. 70 .

75 According to the CJEU, a customs authority can act when there are indications before it that one or more of the operators involved in the manufacture, consignment or distribution of the goods in warehousing or transit, while not having yet begun to direct the goods towards EU consumers, are about to do so or are disguising their commercial intentions. See Philips v. Nokia, above note 71 , at para. 6o.

76 Ibid., at paras. 61 and 71 .

77 Okazaki, note 40 , at 17 . 
alternative consists of anticipating the moment and location of the protection. This is the model followed by Switzerland, where the patent owner can impede the transit of patent-infringing goods if he can also prohibit the import into the country of destination. ${ }^{78}$ Hence, Swiss law permits anticipating the moment of the protection that the same title holder could demand in the country of destination. Although it relates to patents, Swiss authorities justify such anticipation in view of the increasing international dimension of counterfeiting and piracy, ${ }^{79}$ and in order to 'prevent Switzerland from becoming a transit country for pirated goods' ${ }^{80}$ In the context of trademark law, the EU has also made relevant the law of the final country of destination. In the EU, the entitlement of the trademark proprietor to detain products in transit shall lapse if, in the context of customs procedures, "evidence is provided by the declarant or the holder of the goods that the proprietor of the registered trade mark is not entitled to prohibit the placing of the goods on the market in the country of final destination, ${ }^{8}$

Naturally, should border authorities have direct and speedy access to the database of intellectual property offices from all over the world, they could also rapidly verify whether the IP owner who claims to have the right to impede importation to the country of destination is entitled to do so. It is difficult to envisage such a system to function ex officio, but it would accelerate procedures if the process were initiated at the request of an interested party. The same applies in respect to the holding made by the proprietor or consignor of the goods in the example provided regarding the EU. Advanced analytics allows to correlate internal data with other categories of data. In particular, it allows to correlate the customs situation, national intellectual property and international intellectual property protection status in the country of destination. Thus, putting existing sources of information and technologies at work for the benefit of customs authorities would make it more feasible to meet standards that, right now, are rather difficult to attain because of technical and resourcerelated constraints.

\section{Challenges}

While big data and AI bring about new opportunities in the context of IP enforcement, including customs enforcement, new challenges also emerge. On this

$7^{8}$ See Article 8.3 Swiss Federal Act on Patents for Inventions (PatA) of 25 June 1954 (Status as of 1 April 2019); also Swiss Federal Institute of Intellectual Property, Interpretation of the Patents Act, available at www.ige.ch/fileadmin/user_upload/recht/national/e/Auslegeordnung_Patentgesetz_e .pdf.

79 Ibid.

8o Ibid.

${ }^{81}$ See Article 10.4 and Recital 23 Directive 2015/2436 of the European Parliament and of the Council of 16 December 2015 to Approximate the Laws of the Member States Relating to Trade Marks, OJ L [2015] 336/1. 
occasion, concerns arising from automation of the law and due process restrictions become also of relevance in respect of border enforcement.

In contrast to the TRIPS standard of releasing the goods that have been detained while in transit, the $\mathrm{EU}$ has put in place a speedy process for the destruction of goods suspected - but not confirmed - of infringing IPRs. TRIPS mandates the release of goods in case proceedings leading to a decision on the merits of the case have not been initialed or provisional measures have not been adopted within a period of ten working days after the applicant has been served notice of the suspension. ${ }^{82}$ However, the EU has inverted the logic behind this rule and has established that the destruction of the goods will follow, without any further procedure on the merits of the case, if the alleged infringer does not respond in due time to the seizure. ${ }^{83}$

It is predictable that the automation of procedures will result in more cargos being detained and more notifications of such detentions being sent to the owners of the cargos. However, economic and operational difficulties to respond to this type of processes, taking place in different continents and eventually exceeding what small companies can afford, will persist. In many instances, the owner of the goods may not contest the detention because, for instance, doing so may be more expensive than the value of the parcel that has been detained, or just for lack of knowledge or lack of time to react. If other, compensatory, measures - also of a technological nature - are not introduced, due process standards, in particular the right to a fair hearing and the presumption of innocence, become clearly threatened, especially when the right holder does not even need to start procedures on the merits of the case.

Reflections made by Citron in respect of due process and algorithmic enforcement, and the need to ensure that analytical algorithms satisfy standards of review guaranteeing fairness and accuracy, are fully applicable to customs enforcement. ${ }^{84}$ A number of actions would mitigate those concerns. First, it is necessary to improve transparency (or at least the understanding) of the algorithms that determine which cargos and goods will be detained and inspected. ${ }^{85}$ Next, it is also necessary to allow challenging the decision and detention undertaken with the assistance of automated

82 Article 55 TRIPS.

83 EU Regulation No $1383 / 2003$ allowed a procedure for destroying certain goods without there being any obligation to initiate proceedings to establish whether an intellectual property right has been infringed. EU Regulation No 608/2013 has made the procedure compulsory with regard to all IP infringements and orders to apply it where the declarant or the holder of the goods does not explicitly oppose destruction.

84 D. K. Citron, 'Technological Due Process', Washington University Law Review 85 (2008), 1301-1333.

85 On lack of transparency of algorithmic decision making, see Perel and Elkin-Koren, note 17, at 517-518. The central features of algorithms do not make things easy: 'Algorithms are nontransparent by nature; their decision-making criteria are concealed behind a veil of code that we cannot easily read and comprehend. Additionally, these algorithms are dynamic in their ability to evolve according to different data patterns. This further makes them unpredictable'. Perel and Elkin-Koren, note 15, at 190. 
mechanisms. Finally, it must also be possible to enable public oversight of automated border enforcement. ${ }^{86}$ In reality, these concerns are not really different from those expressed in other areas of IP enforcement where automation has become a common practice, as discussed earlier.

\section{E CONCLUSIONS}

Digitalization, big data and distributed ledger technologies drastically change law enforcement. When applied to customs control, as it happens in other domains, these technologies result in cost savings and promote more efficient and less-proneto-error administrative, judicial and commercial processes. Interconnectedness, instant access to foreign databases and constant monitoring of the precise location of goods allow to implement, for instance, standards relating to the control of goods in transit that were difficult to meet until now. Similarly, AI functional applications, such as image recognition, combined with the possibility to constantly and exponentially learn from past events, strengthen systems to control internationally traded goods protected by intellectual property rights.

Together with opportunities, challenges of both technical and legal nature also arise. Technical challenges are still manifold and relate to aspects such as the low quality and heterogeneous formats of digitalized data feeding AI functional applications. Legal concerns expressed in respect of algorithmic law enforcement relate to transparency, accountability and contestability of decisions. These concerns, which are of a general nature, are also of relevance to customs enforcement, as seen in the case of the automation of decisions concerning goods in transit. Algorithmic law enforcement must respond to the mentioned challenges and acknowledge in particular that intellectual property enforcement is a process of weighing and balancing rights and interests of different nature, and not an automated process to implement a predefined decision. Discretion and proportionality are central in the enforcement process, but these are attributes of remedies that require human virtues and skills that the current level of technological development does not seem capable to replicate yet.

86 For similar analysis but in the area of copyright enforcement, see Perel and Elkin-Koren, note 17 , at 476 . 